\title{
WHY SHOULD PUBLIC SERVICE MOTIVATION IMPORTANT FOR VILLAGEDEVELOPMENT
}

\author{
By \\ Oldy Arnoldy ${ }^{1}$, Johannes ${ }^{2}$, Edward $^{3}$, Shofia Amin ${ }^{4}$ \\ ${ }^{1}$ Doctorate student at Doctorate Postgraduate Program, University of Jambi \\ ${ }^{2,3,4}$ Lecturers at Post Graduate Program, University of Jambi \\ Email: johannes@unja.ac.id
}

\begin{tabular}{|c|c|}
\hline Article Info & ABSTRACT \\
\hline $\begin{array}{l}\text { Article History: } \\
\text { Received:13-10-21 } \\
\text { Revised : 16-11-21 } \\
\text { Accepted: } 24-11-2021\end{array}$ & $\begin{array}{l}\text { The developmentphilosophy by Indonesia is change, starts from the village to correct } \\
\text { previous development practices. Hence, public service motivation is essential to } \\
\text { promote village development. So, the purpose of this study is to examine the direct } \\
\text { and indirect effects of transformational leadership and organizational culture on } \\
\text { public service motivation.The methodology accordingly includes a seven-item scale } \\
\text { questionnaire survey consisting of } 210 \text { samples of village officials. We used the }\end{array}$ \\
\hline $\begin{array}{l}\text { Keywords: } \\
\text { Village Officials, Public Service } \\
\text { Motivation, Transformational } \\
\text { Leadership, And } \\
\text { Organizational Culture. }\end{array}$ & $\begin{array}{l}\text { structural model, fit model, and mediation model to test the hypothesis and allow } \\
\text { SmartPLS.The result showed that public service motivation is directly influenced by } \\
\text { transformational leadership and organizational culture. Indirectly, public service } \\
\text { motivation is influenced by transformational leadership mediated by organizational } \\
\text { culture. Hence transformational leadership is the essential thing that should be } \\
\text { implemented by the village official where they needed to empower. In line with it, } \\
\text { organizational culture has a mediation role in improving public service motivation. } \\
\text { Hence, the local role of government is expected to empower the village's } \\
\text { organizational environment to make the village more positional. }\end{array}$ \\
\hline & Thisisan open accessarticleundertheCC BY-SAlicense. \\
\hline $\begin{array}{l}\text { CorrespondingAuthor: } \\
\text { Johanes, } \\
\text { Lecturers at Post Graduate Program, } \\
\text { University of Jambi, } \\
\text { Email: johannes@unja.ac.id }\end{array}$ & \\
\hline
\end{tabular}

\section{INTRODUCTION}

Law Number 6 of 2014 states that the village is a legal community unit that has territorial boundaries to regulate government and the interests of its people to improve the quality of life and community welfare. The village government is the village head assisted by village officials consisting of the village secretary, technical implementers, and regional implementers.

Village government existed before Indonesia was proclaimed, but the current condition of village development is slow, far behind the city, only carrying out administrative activities, and low capacity in building human resources and village infrastructure (Torau, 2019). The village head has the authority to set village regulations, the issuance of village regulations at village meetings can be a tool to answer various kinds of important problems on the economic and social side so that the community can become independent (Wahyudin et al., 2016).

The measurement of village development progress in Indonesia is described through the Village Development Index (IDM), which aims to support the central government in increasing villages to become independent and reducing disadvantaged villages. The description of Jambi Province villages based on IDM in 2020 is categorized into five categories. They are independent (87 villages), developed (285 villages), developing (871 villages), underdeveloped (154 villages), and very underdeveloped (2 villages). The existence of villages with the status of being left behind and very underdeveloped (156 villages) is a real problem in this study.

One of the factors that cause villages to be left behind is the low performance of village officials. Some research identified factors that affect performance: influenced by individual work behavior (Regen et al., 2020), quality of planning (Wazirman et al., 2020), creativity and innovation (Amin \& Jaya, 2019), leadership style, culture, 
and organization (Aryanto et al., 2014), professionalism and competence (Kadarsih \& Edward, 2014), job satisfaction, and organizational commitment (Ningsih \& Johannes, 2013).

The quality of village public services can be influenced by performance (Watkaat, 2020). Performance can exceed the target set by strengthening extra tasks other than the main task Chiniara\& Benin, 2017). This extra task theoretically is known as organizational citizenship behavior (OCB). It includes individual behavior with the natural substance of helping, enlivening work enthusiasm, being on time, being present outside of working hours, not complaining, being polite, solving problems, playing a modern (fashionable) role, and avoiding unexpected work (Organ, 2015).

Village officials are obliged to empower the community for their independence and welfare, in carrying out this empowerment, it is important to provide excellent public service motivation because village officials are community servants (Chalik \& Habibullah, 2015). Forms of implementing excellent public service motivation, including; complaint services, information management, internal control, counseling, and consultation (Thamrin, 2013).

Public service motivation (PSM) is defined as an individual's concern for serving the community governed by the organization, stemming from public policy interest, public interest commitment, compassion, and self-sacrifice (Perry et al., 2010). Public service motivation arises due to the loss of public trust in the government, and this term is often used as a synonym for government services in the public sector in the form of individual attitudes not to carry out personal interests, behave ethically and innovatively (Perry \&Hondeghem, 2008).

Transformational leadership is a leadership style that motivates individuals for closer relationships, inspires, offers challenges, and encourages individual abilities (Bass \&Riggio, 2006). Organizational culture is the shared understanding of individuals in recognizing bureaucracy and innovation in supporting teamwork in their work environment (Cameron \& Quinn, 2011). PSM and OCB are positively influenced by transformational leadership (Mandla, 2020). In addition, transformational leadership positively influences organizational culture (Khan et al., 2020).

It has been found that the positive influence of transformational leadership and organizational culture on the performance of village officials (Laras\&Haryono, 2016). In addition, organizational culture was also found to have a direct and indirect positive effect on public service motivation and OCB, but an indirect negative relationship was also found between transformational leadership and organizational culture (Fitro et al., 2021 \&Shibamy et al., 2019).

Previous researchers found a different relationship, and this is a theoretical problem of this study. The difference is the basis for testing the motivation of public services that are influenced by transformational leadership and organizational culture either directly or indirectly to village officials.

\section{LITERATURE REVIEW}

\subsection{Public Service Motivation}

Perry et al. (1990) firstly stated public service motivation as the tendency of individual employees to provide services to the community to do good for others. This concept was originally used to distinguish the form of public service motivation in public sector employees and private sector employees, and the idea is that public sector employees are more concerned with doing work that benefits society and helps others. In contrast, private-sector employee's value extrinsic rewards more (Mandla, 2020).

Although several authors explain other definitions, Perry et al. (2010) argue that all these definitions support each other by emphasizing different aspects of the same phenomenon. In essence, the PSM theory opposes individuals acting for their own sake; the main goal in PSM is the satisfaction of serving the public, self-sacrifice to put the good of society above personal interests (Boyd \&Nowell, 2020).

What motivates employees to submit innovative ideas, spend a lot of time working, and without being rewarded? The answer is not in finance, but their desire, especially if their work contributes to the organization (Christensen et al., 2017). Individual prosocial behavior that many researchers pay attention to is organizational citizenship behavior (OCB). It includes the freedom of individual behavior that does not directly promote efficient and effective organizational functions, such as; helping, awareness, obedience, sportsmanship, and defending the organization (Organ, 1988).

Piatak\&Holt (2020) found that PSM positively affects OCB directly and as a mediation. Individuals with high PSM tend to show high levels of OCB as well (Abdelmotaleb\&Saha, 2019). PSM is directly and indirectly influenced by transformational leadership and organizational culture (Marques, 2020).

In carrying out its functions, the inner village government should have accuracy in recruiting employees because they serve as community servants. Christensen et al. (2017) mention that PSM is used as a tool in employee recruitment to understand work tasks based on PSM values. Chalik\&Habibullah (2015) explained the obstacles for village PSM in regard to service procedures that have been set but are not realized, the difficulty of accommodating 
International Journal of Social Science (IJSS)

Vol.1 Issue.4 December 2021, pp: 373-384

ISSN: 2798-3463 (Printed) | 2798-4079 (Online)

DOI: https://doi.org/10.53625/ijss.v1i4.715

the many wishes of the community, disturbances such as power outages, and computer damage, swelling of the budget that has been set.

\subsection{Transformational Leadership and PSM}

Can leadership improve PSM? Transformational leadership has a strong relationship with PSM. Leaders should encourage employees to maintain contacts outside the organization to access relevant information as a resource available within the organization (Schwarz et al., 2020). Leadership that serves public employees by emphasizing the wider community's importance will increase employee PSM (Schwarz et al., 2016). Transformational leadership is very useful in public and non-profit organizations because it is oriented towards community service. Several studies have shown that transformational leadership is effective in the public sector (Mandla, 2020).

Transformational leadership contributes to job satisfaction and improvement in PSM; the findings of previous studies confirm that transformational leadership behavior is positively correlated and directly affects employee PSM (Vandenabeele et al., 2014). Using statistical methods in analyzing scientific publications between transformational leadership and PSM, Marques (2020) has collected and analyzed 61 publications on leadership, and public service motivation. The findings of publications began in 2003, and 74\% of articles were widely published from 2014 to 2015.

Publication of leadership and public service motivation is widely published in the journal Public Administration Review (10 journals), International Public Management Journal (8 journals), and Public Management Review journal ( 8 journals). Of the 61 published articles, 129 have been written by experts, with the most prolific authors being Bradley E. Wright (5 articles), Robert K. Christensen (4 articles), Sanjay K. Pandey (4 articles).

2.3. Organizational Culture and PSM

How to support organizational culture in order effect on PSM? Organizational culture must formulate individual beliefs, attitudes, perspectives, and behaviors for public service motivation by touching on group culture, hierarchical culture, and rational culture $(\mathrm{Go}, 2013)$. Because it is difficult to examine the level of PSM for new employees, organizational culture is an important factor influencing the perspectives and attitudes of PSM employees in the long term (Pyo, 2013). Culture affects performance moderated by norm-based PSM (Lee et al., 2019). Organizational culture also affects PSM, which moderates organizational commitment (Austen \&Zacny, 2015).

Christensen \& Wright (2011) suggest that PSM is less related to employee attitudes but has more to do with the cultural values adopted by the organization. Thus, PSM can be enhanced or undermined by organizational culture, and organizational culture is an important factor in shaping the level of PSM (Massaras et al., 2014).

\subsection{Village Official's $P S M$}

It is very important to improve the ability of village officials to carry out the guidance and supervision of community service tasks. Observations showed that village officials were found that were not yet optimal; for example, there are still few services for public administration processes, lack of ability to operate computers, and low levels of work discipline (Mariani, 2021).

Village officials face difficulties due to many factors; the difficulty of accommodating the interests of the community, increasing village expenditures, potential management is not optimal, village policies are less effective, village regulations are not yet implemented, low ability to make village proposals (Watkaat, 2020). The solution is implementing services, management of public complaints, information management, internal control, counseling to the community, and consulting services (Thamrin, 2013).

\subsection{Hypothesis}

The Village Government is assigned to encourage improving the quality of development in the village based on the principle, legal certainty, orderly administration, orderly public interest, openness, proportionality, and professionalism. In carrying out their duties, the Village Head is responsible for leading, coordinating, and providing guidance and instructions for implementing the duties of their respective subordinates.

Transformational leadership is a factor that influences public service motivation (Marques, 2020). By observing the description in the literature review, the proposed hypothesis is as follows;

$\mathrm{H}_{1}$ : Directly, transformational leadership has a positive and significant effect on the motivation of public service.

Then, transformational leadership is also able to directly and positively influence organizational culture (Nam \& Park, 2019), so the hypothesis is proposed as follows;

$\mathrm{H}_{2}$ : Directly, transformational leadership has a positive and significant effect on organizational culture. 
Kim (2017) has provided support that national culture is associated with PSM. Anderfuhren-Biget et al. (2014) also found that organizational culture influences PSM. By looking at the description in the literature review, the proposed hypothesis is as follows;

$\mathrm{H}_{3}$ : Organizational culture has a positive and significant effect on motivation for public service.

There are no indirect findings between transformational leadership on the motivation of public service mediated by organizational culture, so the proposed hypothesis is as follows;

$\mathrm{H}_{4}$ : Indirectly, transformational leadership positively and significantly affectspublic service motivation mediated by organizational culture.

\section{METHODS}

The population of this study was 435 villages in the districts of Kerinci and Muaro Jambi. Using Yamane's approach (1973), we found of 210 village officials. Respondents are samples from the Head of Affairs, Head of Section, and Head of Regional.

\subsection{Descriptive Statistics}

Descriptive statistics are used to describe the characteristics of respondents, samples, and research variables. In addition to the use of index numbers, data depiction also uses other descriptive statistical techniques such as the average number (mean).

\subsection{Measurement and Structural Model}

The measurement model (outer model) uses a validity test (convergent validity \& discriminant validity) and a reliability test (composite reliability \&Cronbach's alpha). While the structural measurement model (inner model) uses the R-square value, path coefficient test, t-statistical test, and mediation test.

\subsection{Hypothesis Test}

The first sub-model of this study is to directly examine transformational leadership and culture on the motivation of public servants (hypothesis $\mathrm{H}_{1}-\mathrm{H}_{3}$ ). The second sub-model of this study is a study of the mediating role of organizational culture between transformational leadership and PSM (H4).

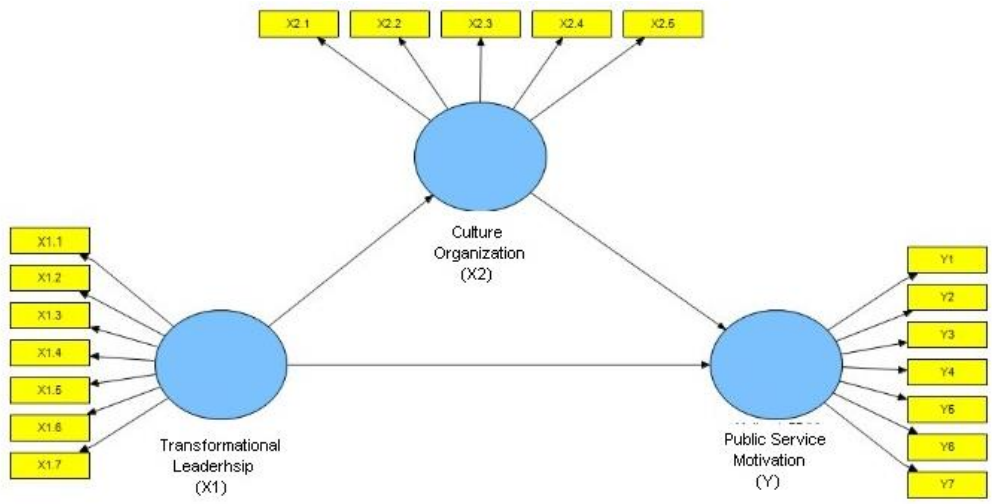

Figure 1.The direct and indirect effect model of transformational leadership on PSM is mediated by the organizational culture of village officials

\subsection{Variable Operations}

Operational variables are carried out to obtain data and information from research variables. The independent variable is given the symbol X1, namely transformational leadership measured using the scale from Antonakis et al. (2003). Then mediation variable is given the symbol X2, namely organizational culture using the scale from Cameron \& Quinn (2011), and the dependent variable is given the symbol Y,namely PSM was measured using a combination of scales from Perry (1996) and Organ et al., (2006).

\section{RESULTS AND DISCUSSION}

\section{Sample Description}

The description of respondents is used to describe the highest number of respondents bycategories so that an overview of the number of village officials is obtained based on age, gender, education, marital status, position, and 
International Journal of Social Science (IJSS)

Vol.1 Issue.4 December 2021, pp: 373-384

ISSN: 2798-3463 (Printed) | 2798-4079 (Online)

tenure of village officials in Jambi Province. Respondents from village officials based on the highest classification in the age category of 30 - 39 years ( 77 respondents/36,7\%), male gender (175 respondents/83.3\%), S1 education level (78 respondents/37,1\%), married (168 respondents / 80\%), and tenure of $4-6$ years (109 respondents / 51,9\%).

\section{Descriptive statistics}

The description of descriptive statistical variables is measured using index and average numbers.The results show transformational leadership has an index number of 73.78 (high category/average 5.16). Organizational culture has an index number of 86.04 (high category/average 6.05). PSM has an index number of 86.64 (high category/average 6.06).

\section{Measurement and Structural Model}

The measurement model (outer model) uses a validity test (convergent validity \& discriminant validity) and a reliability test (composite reliability \& Cronbach's alpha). All indicators in each variable have a loading factor value of $>0.70$ (valid) so that it meets convergent validity. While for the AVE value $>0.50$, this value has met the requirements in accordance with the minimum value limit, the results of the Fornel Larcker Criterion value show the comparison value of the variable itself is greater than the value of other variables and is eligible to enter the discriminant validity test category. The reliability test was estimated by calculating composite reliability and Cronbach's alpha based on standardized loading. All variables have a composite reliability value, and Cronbach's alpha $>0.70$ has met the requirements.

The structural measurement model (inner model) uses the R-square value, path coefficient test, t-statistical test, and mediation test. R-square analysis shows that $\mathrm{X} 1$ is able to explain $\mathrm{X} 2$ by $9.8 \%$. At the same time, $\mathrm{X} 1$ and $\mathrm{X} 2$ are able to explain the variability of $\mathrm{Y}$ by $10.1 \%$.Path coefficient test is used to see the direction of the relationship of the independent variable to the dependent variable. The direction of the relationship is seen from the positive or negative coefficient value. The results of data management in this study can be seen in Figure 4.1.

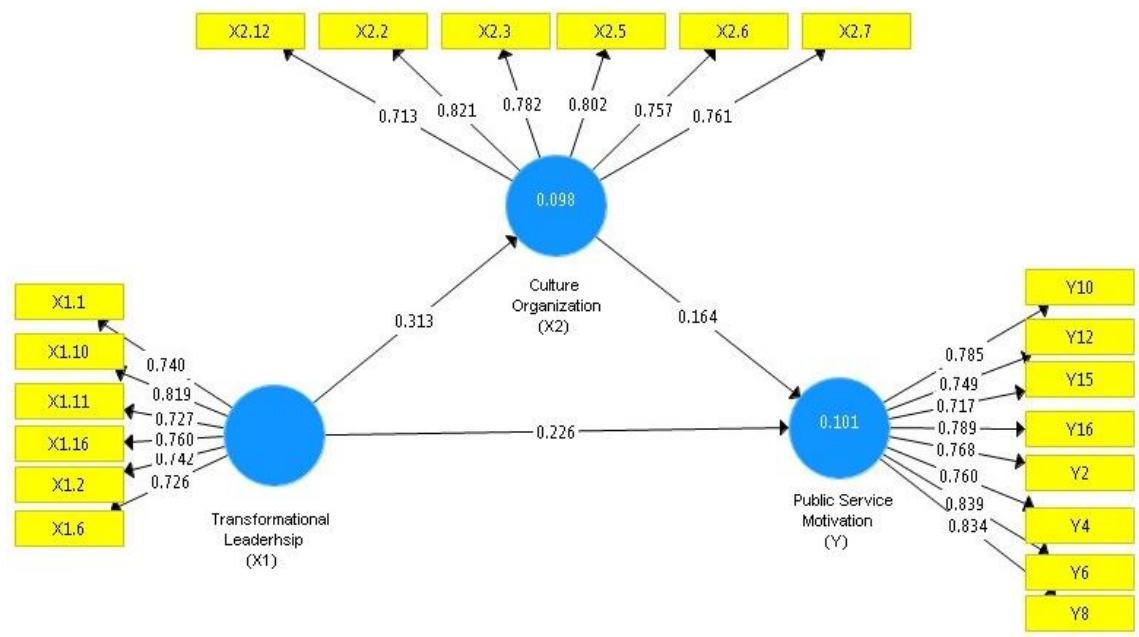

Figure 2. Path coefficient model test of the direct effect of transformational leadership on the PSM is mediated by organizational culture in village officials

The results of Figure 4.1 show that all independent variables on the dependent variable have values above zero and are positive. This means that the relationship has a positive value to the variables studied.

Furthermore, t-statistic test or signification used to examine effect of an independent variable on the dependent variable. The t-statistic value with a deviation of $5 \%$ must be greater than the t-table value (> 1.96). The results of data management on the value of the t-statistical test in this study can be shown in Figure 4.2 


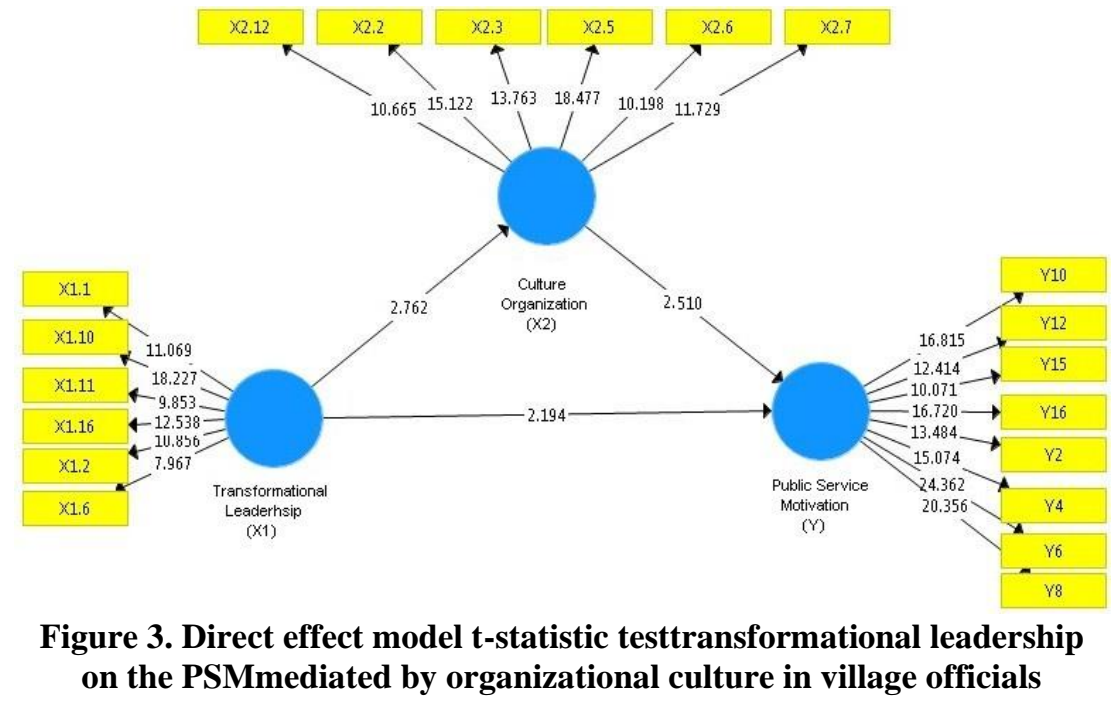

Figure 3 explains that the t-statistic value of transformational leadership affects organizational culture and $\operatorname{PSM}(2.762 \& 2.102)$, organizational culture affects PSM (2.512). All t-statistical value variables have a significant effect because it is $>1.96$.

The significance level or p-value of 0.05 on the influence of transformational leadership on organizational culture and PSM $(0.007 \& 0.036)$ and the influence of organizational culture on PSM $(0.031)$ explained that all pvalues were $<0.05$ and concluded the effect significantly.

The mediation test used organizational culture as a mediator of transformational leadership on PSM. The original sample value or the coefficient value of the indirect relationship $(0.251)$ explains that every $100 \%$ increase in the mediation relationship can only affect an increase in the dependent variable by $25 \%$. The t-statistic value (2.143) explained that the indirect effect was significant $(<1.96)$. P-values $(0.034)$ explained that this indirect relationship had an effect $(<0.05)$. The mediating variables were found to be partial mediation. Mediation is referred to as partial mediation when the dependent variable remains significant without or with a mediating variable (Baron \& Kenny, 1986).

Hypothesis Test

This research hypothesis test support that transformational leadership is significant to PSM, transformational leadership is significant to organizational culture, andorganizational culture is significant to PSM. Transformational leadership on PSMmediated by organizational culture $\left(\mathrm{X}_{2}\right)$ has a significant relation.

Discussion

The village head's transformational leadership style has a significant effect on PSM, and this research is in line with Marques (2020) and Miao, et al. (2018), who mentioned that transformational leadership is a factor that affects PSM. Furthermore, it is not in line with Mandla public (2020), which negatively influences the relationship.

The village government in carrying out PSM must have accuracy in recruiting employees because they serve as public services. Christensen et al. (2017) emphasize that PSM is used for employee recruitment because of their duties as public services.The importance of PSM is due to the loss of public trust in the government. Ambarwati\&Lestariana (2020) explained that the quality of public services is a factor in increasinggovernment trust. Added by Mulyadi (2018) and Mulyawan (2017), the government provides all public services because they cannot meet their own needs.

Chalik\&Habibullah (2015) explained that village officials are obliged to empower the public to be independent and welfare because village officials are public services. Hence, effective empowerment needs to be strengthened because, in the field, it is still found that village officials cannot operate computers, have low public administration process services, and have low levels of discipline (Mariani, 2021). Robust village official public services, including; public complaint services, information management, internal control, counseling, and consultation (Thamrin, 2013).

The problem of village officials in public services, according to Watkaat's (2020), is the difficulty of meeting the many public interests, the difficulty of regulating policies that are not in accordance with village regulations, inadequate facilities, and infrastructure that hinder the filing of letters, swelling of the village fund budget, low management of village potential and incomplete development proposals.

What motivates employees to develop innovative ideas and spend a lot of time working for no real reward? Christensen et al. (2017) explain the answer is not in financial incentives, but they desire to serve the public, 
International Journal of Social Science (IJSS)

Vol.1 Issue.4 December 2021, pp: 373-384

ISSN: 2798-3463 (Printed) | 2798-4079 (Online)

DOI: https://doi.org/10.53625/ijss.v1i4.715

especially their work to contribute to the mission of their organizations. Abdelmotaleb\&Saha (2019) added that individuals with a high level of public service motivation tend to show a high level of organizational citizenship behavior.

PSM was found to directly affect organizational citizenship behavior (Piatak\& Holt, 2020). Individual public services with work behavior for the public interest are considered successful (Elbanna et al., 2016). The impact of PSM will increase organizational commitment and organizational citizenship behavior and satisfy the basic psychological needs of employees (Belrhiti et al., 2020). In addition, PSM can increase job satisfaction, individual fit to the organization, and organizational effectiveness (Prysmakova, 2020).

Perry (2000) and Camilleri (2007) asserted that PSM results from the organizational environment around them. Perry (1996) has researched that PSM develops from childhood experiences, religious teachings, education, and professional life caused by parental socialization, professional identification, political ideology, and individual demographics.In essence, the PSM theory opposes individuals acting for their self-interest for their motive to serve the public, self-sacrifice for society above self-interest is the root of public service motivation (Perry, 2000).

Can leadership improve PSM? Paarlberg\&Lavigna (2010) stated that leadership behavior is often studied as a cause of PSM in employees. Marques (2020) added that transformational leadership and PSM are two research topics that have received attention recently. Then, Miao et al., 2018) added the key transformational leadership of PSM.Research on the relationship between transformational leadership and PSM tends to be carried out incorporate or local government organizations (Caillier, 2020). But it has not been found in the village officials. This is the first new finding in this study.

Significant findings on the relationship of transformational leadership to organizational culture in this study have been supported by previous studies, although they cannot be concluded. The results of this study are in line with Mekic et al., (2020) and Nam \& Park (2019), who have found a positive relationship between transformational leadership and organizational culture. However, this is not in line with Shibamy et al. (2019), who found a negative relationship.

The organizational culture of village officials that occurs is seen from the developing village index published by the Ministry of Villages. In recent years, the villages of Jambi province have experienced changes in the village development index from underdeveloped villages to developing and then developed villages.

Saputri\&Muhsin (2018) found that the problem with the organizational culture of village officials is that services are often carried out at home compared to village offices. As a result, village officials have a less friendly attitude in providing services and rigid procedures so that services to the community are stagnant and less than perfect (Laras\&Haryono, 2016).

Musyodik et al. (2021) said that the organizational culture of innovative village officials such as; controlling risk, conscientiousness, initiative, attentive, consistent results, self-development, and not procrastinating on work.Leadership and organizational culture have a long, varied, and unpredictable history (Khan et al., 2020). Leadership is significantly related to organizational culture and business excellence (Wiengarten et al., 2015). However, leadership styles vary for different organizational cultures (Perry et al., 2010).

Research on the relationship between transformational leadership and organizational culture tends to be carried out in corporate or government organizations (Al-Shibami et al., 2019\&Fitrio et al., 2021). However, it has not been found in village officials. This is the second new finding in this study.

Cameron \& Quinn (2011) explained that diagnosing organizational culture uses the Organizational Culture Assessment Instrument (OCAI). Therefore, OCAI makes it possible to analyze the dominant organization based on the type of culture, such as; hierarchical culture, market culture, clan culture, and adhocracy culture.This study found that the organizational culture of the village officials studied had a hierarchical type of organizational culture. Cameron \& Quinn, (2011) explain that the hierarchical type of organizational culture is an ideal, stable, efficient, and highly consistent organizational form because the environment is relatively stable, integrated, and coordinated, uniform and controlled workers and work.

The organizational culture of village officials also affects village-level PSM. The findings of this study are supported by the results of previous studies by Lee et al.(2019) and Kim (2017). Christensen and Wright (2011) assert that public PSM can be enhanced or undermined by organizational culture.Public service motivation is a universal variable that can be measured through customs and traditions, and culture. Gupta et al. (2020) explained that the impact of PSM on village officials is that it makes it easier to know village planning and development, provides consultation facilities for complaints and problems, and makes it easier to receive village administrative services.

The form of service in the public sector is the attitude of individuals not to carry out personal interests, to behave ethically and innovatively (Perry \&Hondeghem, 2008). Public servant motivation is directly influenced by 
transformational leadership and organizational culture (Marques, 2020). In this study, the transformational leadership of the village head had a positive effect on PSM, which was mediated by the organizational culture of the village officials, but no previous research has found this relationship. This is the third finding in this study.

The organization's success requires individuals who provide extra tasks in addition to the main task and exceed the organization's goals. This extra task term is known as organizational citizenship behavior. Organizational citizenship behavior has overcome public organizational gaps and improved PSM behavior at the individual, group, and organizational levels (Geus et al., 2020).

Previous research has found a strong interrelationship between organizational citizenship behavior and PSM (Alanazi, 2020; Cheng, et.,2020). There are similarities in the dimensions of the two variables, and this study combines them, but no previous research has been found for combining these dimensions.

The research results are accordinglyin line with many by previous research. So, here are the conclusions.

\section{CONCLUSION}

Based on the results of data processing and discussion in this study, it can be concluded as follows;

1. The influence of transformational leadership on PSM has a positive and significant effect on village officials.

2. The influence of transformational leadership on culture has a positive and significant effect on village officials.

3. The influence of organizational culture on PSM has a positive and significant effect on village officials.

4. The influence of transformational leadership on PSM mediated by organizational culture positively and significantly affect village officials.

5. The organizational culture found in village officials is a type of hierarchical organizational culture.

\section{REFERENCE}

[1] Abdelmotaleb, M., \& S. K. Saha. (2019). Corporate Social Responsibility, Public Service Motivation and Organizational Citizenship Behavior in the Public Sector. International Journal of Public Administration, 42(11), 929-939.

[2] Al-Shibami, A. H., Alateibi, N., Nusari, M., Ameen, A., Khalifa, G. S. A., \& Bhaumik, A. (2019). Impact of organizational culture on transformational leadership and organizational performance. International Journal of Recent Technology and Engineering, 8(2 Special Issue 10), 653-664. https://doi.org/10.35940/ijrte.B1116.0982S1019

[3] Alanazi, L. (2020). Does Gender Matter ? Testing the Mediating Role of Public Service Motivation between Gender and Organizational Citizenship Behavior in Federal Agencies Does Gender Matter? Testing the Mediating Role of Public Service Motivation between Gend. International Journal of Public Administration, 1-11. https://doi.org/10.1080/01900692.2020.1729187

[4] Ambarwati, R., \& Lestariana, F. (2020). Citizen trust in local government: Explaining the role of village service (1st Editio). CRC Press.

[5] Amin, S., \& Jaya, I. (2019). Creativity and innovation in achieving success in traditional cake businesses. Jurnal Perspektif Pembiayaan Dan Pembangunan Daerah, 2(3), 222-231.

[6] Anderfuhren-Biget, S., Varone, F., \& Giauque, D. (2014). Policy environment and public service motivation. Public Administration, 92(4), 807-825. https://doi.org/10.1111/padm.12026

[7] Antonakis, J., Avolio, B. J., \& Sivasubramaniam, N. (2003). Context and leadership : an examination of the ninefactor full-range leadership theory using the multifactor. The Leadership Quarterly, 14, 261-295. https://doi.org/10.1016/S1048-9843(03)00030-4

[8] Aryanto, Johannes, \& Edward. (2014). Pengaruh gaya kepemimpinan dan budaya organisasi terhadap kinerja pegawai. Jurnal Dinamika Manajemen, 6(4), 435-444.

[9] Austen, A., \& Zacny, B. (2015). The role of Public Service Motivation and Organizational Culture for Organizational Commitment. Management, 19(2), 21-34. https://doi.org/10.1515/manment-2015-0011

[10] Baron, R. M., \& Kenny, D. A. (1986). The moderator-mediator variable distinction in social psychological research: Journal of Personality and Social Psychologynality and Social Psychology, 51(6), 11. https://doi.org/10.1177/1350506818764762

[11] Bass, B. M., \& Riggio, R. E. (2006). Transformational Leadership. In Lawrence Erlaburn Associates (Second). https://doi.org/10.1017/CBO9781107415324.004

[12] Belrhiti, Z., Van Damme, W., Belalia, A., \& Marchal, B. (2020). The effect of leadership on public service motivation: A multiple embedded case study in Morocco. BMJ Open, 10(1), 1-3. https://doi.org/10.1136/bmjopen2019-033010

[13] Boyd, N. M., \& Nowell, B. (2020). Sense of community, sense of community responsibility, organizational commitment and identification, and public service motivation: a simultaneous test of affective states on employee 
International Journal of Social Science (IJSS)

Vol.1 Issue.4 December 2021, pp: 373-384

ISSN: 2798-3463 (Printed) | 2798-4079 (Online)

DOI: https://doi.org/10.53625/ijss.v1i4.715

well-being and engagement in a public service work context. Public Management Review, 22(7), 1024-1050. https://doi.org/10.1080/14719037.2020.1740301

[14] Caillier, James Gerard. (2020). Testing the Influence of Autocratic Leadership, Democratic Leadership, and Public Service Motivation on Citizen Ratings of An Agency Head's Performance. Public Performance and Management Review, 43(4), 918-941. https://doi.org/10.1080/15309576.2020.1730919

[15] Cameron, K. S., \& Quinn, R. E. (2011). Diagnosing and Changing Organizational Culture (Third Edit). JosseyBass.

[16] Camilleri, E. (2007). Antecedents affecting public service motivation. Personnel Review, 36(3), 356-377. https://doi.org/10.1108/00483480710731329

[17] Chalik, A., \& Habibullah, M. (2015). Pelayanan Publik Tingkat Desa. Interpena.

[18] Cheng, Kuo-taiChang, Y. C., \& Lee, C. (2020). The Effect of Public Service Motivation at Individual, Group, and Organisational Levels of Citizenship Behaviour. Information Resources Management Journal, 33(1), 39-58. https://doi.org/10.4018/IRMJ.2020010103

[19] Chiniara, M., \& Bentein, K. (2017). The servant leadership advantage : When perceiving low differentiation in leader-member relationship quality influences team cohesion, team task performance, and service OCB. The Leadership Quarterly, 1-16. https://doi.org/10.1016/j.leaqua.2017.05.002

[20] Christensen, R. K., \& Wright, B. E. (2011). The effects of public service motivation on job choice decisions: Disentangling the contributions of person-organization fit and person-job fit. Journal of Public Administration Research and Theory, 21.

[21] Christensen, Robert K., Paarlberg, L., \& Perry, J. L. (2017). Public Service Motivation Research: Lessons for Practice. Public Administration Review, 77(4), 529-542. https://doi.org/10.1111/puar.12796

[22] Elbanna, S., Andrews, R., \& Pollanen, R. (2016). Strategic Planning and Implementation Success in Public Service Organizations: Evidence from Canada. Public Manag. Rev, 18(7), 1017- 1042.

[23] Fitrio, T., Budiyanto, \& Agustedi. (2021). The rule of organizational citizenship behavior and innov ative work behavior in mediating the influence of organizational commitment and culture on employee performance. Growing Science, 6, 1351-1360. https://doi.org/10.5267/j.ac.2020.8.014

[24]

[25] Gupta, R., Dash, S., Kakkar, S., \& Yadav, R. (2020). Construct validity of public service motivation in India: a comparison of two measures. Evidence-Based HRM, 1-16. https://doi.org/10.1108/EBHRM-11-2019-0107

[26] Kadarsih, \& Edward. (2014). Pengaruh profesionalisme dan kompetensi terhadap kinerja auditor badan pengawas keuangan. Jurnal Dinamika Manajemen, 2(1), 47-58.

[27] Khan, I. U., Khan, M. S., \& Idris, M. (2020). Journal of Human Behavior in the Social Environment Investigating the support of organizational culture for leadership styles ( transformational \& transactional ). Journal of Human Behavior in the Social Environment, 1-12. https://doi.org/10.1080/10911359.2020.1803174

[28] Khaola, P., \& Rambe, P. (2020). The effects of transformational leadership on organizational citizenship behavior : the role of organizational justice and an affective commitment. Management Research Review, 1-18. https://doi.org/10.1108/MRR-07-2019-0323

[29] Kim, S. (2017). National culture and public service motivation: investigating the relationship using Hofstede's five cultural dimensions. International Review of Administrative Sciences, 83(1), 23-40. https://doi.org/10.1177/0020852315596214

[30] Laras, T., \& Haryono, T. (2016). Kepemimpinan transformasional, motivasi dan budaya organisasi dampaknya terhadap kinerja perangkat desa (Survey Pada Perangkat Desa Kecamatan Temon Kabupaten Kulon Progro Propinsi Daerah Istimewa Yogyakarta). Jurnal Ekonomi, 21(02), 269-289.

[31] Lee, H. J., Oh, H. G., \& Park, S. M. (2019). Do Trust and Culture Matter for Public Service Motivation Development? Evidence From Public Sector Employees in Korea. Public Personnel Management, 1-34. https://doi.org/10.1177/0091026019869738

[32] Mandla, T. (2020). The Effect of Transformational Leadership on Public Service Motivation and Job Satisfaction: The Case of Estonia. Tallinn University of Technology.

[33] Mariani. (2021). Optimalisasi sumberdaya manusia perangkat desa di Desa Bukit Pedusunan Kecamatan Kuantan Mudik Kabupaten Kuantan Singingi. JUhanperak, 2(1), 289-300.

[34] Marques, T. M. G. (2020a). Research on Public Service Motivation and Leadership : A Bibliometric. International Journal of Public Administration, 00(00), 1-16. https://doi.org/10.1080/01900692.2020.1741615

[35] Mulyadi. (2018). Studi Kebijakan Publik dan Pelayanan Publik. Alfabeta.

[36] Mulyawan. (2017). Improvement of public service quality through regional blossoming policy (A study at Ciater sub-district resulted from regional Blossoming of Jalancagak Sub-district Subang Regency West Java). Adv. Soc. Sci. 
Res. J., 4(11).

[37] Musyodik, M., Hendro, O., \& Moelyati, T. A. (2021). Pengaruh Lingkungan Kerja, Budaya Organisasi dan Kepemimpinan Terhadap Kinerja Pegawai Kantor Kecamatan Sanga Desa Kabupaten Musi Banyuasin. Jurnal Ilmu Sosial, Manajemen, Akuntansi Dan Bisnis, 2(1), 35-53. https://doi.org/10.47747/jismab.v2i1.187

[38] Nam, K. A., \& Park, S. (2019). Factors Influencing Job Performance: Organizational Learning Culture, Cultural Intelligence, and Transformational Leadership. Performance Improvement Quarterly, 32(2), $137-158$. https://doi.org/10.1002/piq.21292

[39] Ningsih, \& Johannes. (2013). Pengaruh kepuasan kerja dan komitmen organisasi terhadap kinerja pegawai pemerintah. Jurnal Dinamika Manajemen, 1(2).

[40] Organ, D. W. (1988). Organizational citizenship behavior: The good soldier syndrome. MA: Lexington Books.

[41] Organ, Dennis W, Podsakoff, P. M., \& Mackenzie, S. B. (2015). Its Nature, Antecedents, and Consequences. SAGE Publications, Inc. https://doi.org/10.4135/9781452231082

[42] Paarlberg, L. E., \& Lavigna, B. (2010). Transformational Leadership and Public Service Motivation: Driving Individual and Organizational Performance. Symposium on Public Service Motivation Research, 70(5), 710-718. https://doi.org/doi:10.1111/j.1540-6210.2010.02199.x

[43] Pandey, S. K. E. C. S. (2008). Antecedents and Correlates of Public Service Motivation, in J. L. Perry and A. Hondeghem, Motivation in Public Management. The Call of Public Service. Oxford: Oxford University Press.

[44] Perry, J. L. (1996). Measuring Public Service Motivation : An Assessment of Construct Reliability and Validity. Journal of Public Administration Research and Theory, 6(1), 5-22. https://doi.org/10.1093/oxfordjournals.jpart.a024303

[45] Perry, J. L. (2000). Bringing Society In: Toward a Theory of Public-Service Motivation. Journal of Public Administration Research and Theory, 10(2), 471-488. https://doi.org/10.1093/oxfordjournals.jpart.a024277

[46] Perry, J. L. (2020). Public service motivation: Putting our intellectual capital to work. Journal of Public Affairs Education, 00(00), 1-3. https://doi.org/10.1080/15236803.2020.1855696

[47] Perry, J. L., \& Hondeghem, A. (2008). Building theory and empirical evidence about public service motivation. International Public Management Journal, 11(1), 3-12. https://doi.org/10.1080/10967490801887673

[48] Perry, J. L., Hondeghem, A., \& Wise, L. R. (2010). Revisiting the Motivational Bases of Public Service: Twenty Years of Research and an Agenda for the Future. Public Administration Review, 70(5), 681-690. https://doi.org/10.1111/j.1540-6210.2010.02196

[49] Perry, J. L., Wise, L. R., \& Perry, J. L. (1990). Bases of The Motivational Public Service. Public Administration Review, 50(3), 367-373.

[50] Piatak, J. S., \& Holt, S. B. (2020). Disentangling altruism and public service motivation : who exhibits organizational citizenship behavior ? Public Management Review, 1-25. https://doi.org/10.1080/14719037.2020.1740302

[51] Prysmakova, P. (2020). Contact with citizens and job satisfaction: expanding person-environment models of public service motivation. Public Management Review, OO(00), 1-20. https://doi.org/10.1080/14719037.2020.1751252

[52] Pyo, S. Y. (2013). A study on the effects of organizational culture and job characteristics on public service motivation in the police. Police Research, 13, 191-216.

[53] Regen, R., Johannes, Edward, \& Yacob, S. (2020). Employee development model and an assessment on the perspectives of work behavior, motivation, and performance. Research in Business \& Social Science, 9(2), 56-69.

[54] Saputri, E. D., \& Muhsin. (2018). Peran komitmen organisasi dalam memediasi pengaruh variabel keteladanan pemimpin, kompetensi perangkat desa, dan budaya organisasi terhadap kinerja. EEAJ, 3, 1130-1147.

[55] Schwarz, G., Alexander, N., Brian, C., \& Nathan, E. (2016). Servant Leadership and Follower Job Performance: The Mediating Effect of Public Service Motivation. Public Administration 94(4): 1025-41., 94(4), $1025-1041$.

[56] Schwarz, G., Eva, N., \& Newman, A. (2020). Can Public Leadership Increase Public Service Motivation and Job Performance? Public Administration Review, 80(4), 543-554. https://doi.org/10.1111/puar.13182

[57] Torau, S. (2019). Analisis Kinerja Pemerintah Desa Dalam Pembangunan Masyarakat Di Desa Bontomanai Kecamatan Mangarabombang Kabupaten Takalar. Jurnal Ilmiah Pranata Edu, 1(2), 87-95. https://doi.org/10.36090/jipe.v1i2.602

[58] Vandenabeele, W., Brewer, G. A., \& Ritz, A. (2014). Past, present, and future of public service motivation research. Public Administration, 92(4), 779-789. https://doi.org/10.1111/padm.12136

[59] Wahyudin, S., Arif, S., Wahyudin, K., Nur, K., Murtodo, \& Ismail, A. Z. (2016). Modul Pelatihan Pratugas Tenaga Ahli Pemberdayaan Masyarakat.

[60] Watkaat, A. J. (2020). Penggaruh Kinerja Aparatur Pemerintah Desa Terhadap Mutu Pelayanan Di Desa Tumbur Kecamatan Wertambrian Kabupaten Kepulauan Tanimbar. Jurnal Sekolah TInggi Ilmu Ekonomi Sumlaki, 2(1), 111. 
International Journal of Social Science (IJSS)

Vol.1 Issue.4 December 2021, pp: 373-384

ISSN: 2798-3463 (Printed) | 2798-4079 (Online)

crossref DOI: $\underline{\text { https://doi.org/10.53625/ijss.v1i4.715 }}$

[61] Wazirman, Johannes, \& Edward. (2020). The influence of organizational culture, leadership behavior, civil servants character, and planning quality of government performance. Jour of Adv Research in Dynamical \& Control System, $12(3), 628-634$.

[62] Wiengarten, F., Gimenez, C., Fynes, B., \& Ferdows, K. (2015). Exploring the importance of cultural collectivism on the efficacy of lean practices Taking an organizational and national perspective. International Journal of Operations \& Production Management, 35(3), 370-391. https://doi.org/http://dx.doi.org/10.1108/IJOPM-09-2012-0357

[63] Yamane, T. (1973). Statistics: An introduction analysis. Harper \& Row. 
